\section{Eighth International Congress of the International Society for Cell Biology}

The date of the eighth international congress of the International Society for Cell Biology (Cytology Congress) has been changed from this year to 1954 . It will be held in Leyden during September 1-7, under the presidency of Prof. E. Newton Harvey, of Princeton University, with Prof. P. J. Gaillard, of the Laboratory for Exporimental Histology, University of Leyden, as secretary. Correspondence concerning the Congress should be addressed to Dr. W. H. K. Karstens, Botanical Laboratory, State University, Nonnensteeg 3, Leyden. Full members of the Society and candidates for membership approved by the International Committee are automatically entitled to attend the Congress, and to introduce two guests. Non-members are admitted as space permits, after provision has been made for members and their guests. Any member of the Society may nominate a new member from "those who have made outstanding contributions to cell biology over a period of years". The nominations, with a statement of qualifications and a list of the nominee's publications, should be sent to the secretary of the Society, Prof. J. F. Danielli, Zoology Department, King's College, London, W.C.2.

\section{Endeavour Prizes for Science Essays}

Is order to stimulate younger scientific workers to take an interest in the work of the British Association for the Advancement of Science and to raise the literary standard of scientific writing, Imperial Chemical Industries, Ltd., publishors of Endeavour, are offering a number of prizes for an essay, not exceeding four thousand words, on one of the following subjects: radio-astronomy; colour and chemistry; biology in world affairs; science and safety in transport; science and art; scientific contributions to medicine; scientific societies and their role; and power and civilization. Competitors must be less than twenty-five years of age and must send in their essays by June 1. The prizes will be 50, 25 and 15 guineas, respectively, with two special awards of 5 guineas for competitors less than eighteen, and in addition prize-winners will have their expenses paid for attendance at the British Association meeting to be held in Liverpool during September 2-9. Further details of these awards, which are known as Endeavour prizes, can be obtained from the Assistant Secretary, British Association for the Advancement of Science, Burlington House, Piccadilly, London, W.1.

\section{University of Leeds}

Donations have been made to the University of Leeds as follows: $£ 2,500$ from the Cement and Concrete Association to the Department of Civil Engineering towards the cost of a universal testing machine; $£ 1,100$ from Bolton Leathers, Ltd., to the Department of Leather Industries, for the Boltonia Fellowship for 1952-53 and 1953-54; a gravity-feed stoker, valued at $£ 1,085$, from Crosthwaite Furnaces, and Scriven Machine Tools, Ltd., Leods ; and a grant of $£ 500$ a year (for one year in the first instance), with provision for superannuation purposes for half time assistance and with up to $£ 1,000$ a year for expenses, from the Medical Research Council, to the Department of Experimontal Pathology and Cancer Research, for work on the carcinogenic action of mineral oils.

\section{Colonial Service: Recent Appointments}

ThE following appointments have recently been made in the Colonial Service : E. W. Momber (principal agricultural officer, Nigeria), assistant director of agriculture, Northern Region, Nigeria ; B. E. V. Parham (senior agricultural officer, Fiji), deputy director of agriculture, Fiji; A. M. Anderson (fisheries officer, North Borneo), fisheries officer, Uganda; M. P. Benjamin (assistant agricultural superintendent, British Guiana), agricultural officer, Jamaica; J. O. Jaine (land ranger, Tanganyika), senior land ranger, Tanganyika; I. G. Lumsden (assistant conservator of forests, Northern Rhodesia), assistant conservator of forests, Nigeria; G. H. Rulf (assistant director of grain storage, Tanganyika), director of grain storage, 'Tanganyika; G. G. Rushby (senior game ranger, Tanganyika), deputy game warden, Tanganyika; E. H. Jones, agricultural officer (economist), Uganda; C. A. Waldron, agricultural officer, Tanganyika; H. T. Williams, bacteriologist, Federation of Malaya; A. Rogerson, scientific officer, East Africa High Commission; D. Bates, agricultural survey (cocoa) officer, Gold Coast ; J. Forsyth, entomologist, Gold Coast ; I. A. S. Gibson, mycologist, Forestry Department, Kenya; T. A. Hoffe, veterinary officer, Federation of Malaya; G. S. Scott, provincial tsetse officer, Tanganyika; W. E. Webb, senior scientific officer, forest entomologist, Timber Pest Research Unit, Gold Coast; T. W. W. Wood, assistant conservator of forests, Sarawak.

\section{Announcements}

Two Ramsay Memorial Fellowships, worth $£ 400$ a year plus a grant for expenses not exceeding $£ 100$ a year, are being offered for chemical research; they will normally be tenable for two years. One of the Fellowships will be limited to candidates educated in Glasgow. Further information can be obtained from the Joint Honorary Secretaries, Ramsay Memorial Fellowships 'Trust, University College, Gower Street, London, W.C.1, to whom application forms must be sent not later than April 17.

THE Ministry of Education is arranging a short course in chemistry for teachers from technical colleges, to be held in the Municipal Technical College, Coventry, during July 15-24. The instruction will deal with modern chemical techniques relating to chromatography and to semi-micro-analysis, and will consist of lectures and practical laboratory work. The course will be residential, but local teachers may be accepted as day students; the total charge for board and lodging is $\mathfrak{E} 8$. Further information can be obtained from the Ministry of Education (Teachers Short Courses), 36-38 Berkeley Square, London, W.1.

The British Columbia Research Council at the University of British Columbia, Vancouver, has announced the following new appointments : Chemistry Division: H. Friedeberg (formerly of the University of Birmingham), W. F. Gruber (University of Vienna), H. G. Khorana (University of Cambridge), J. F. Smith (Imperial College of Science and Technology, London) and J. D. H. Strickland (formerly with the Ministry of Supply in Great Britain); Metallurgy Division : I. D. G. Berwick (University of Cambridge), J. G. Parr (University of Liverpool) and J. E. Srawley (formerly with the British Cast Iron Research Association). 